\title{
Feasibility of Ivy (Hedra helix) for landscaping in Seoul, Korea ${ }^{(1)}$
}

\author{
YONG SUK CHUNG ${ }^{(2)}$,YUKYEONG NAM(3), JIN HEE LEE ${ }^{(4)^{*}}$
}

\begin{abstract}
Due to the global warming, Seoul in Korea seems to be plausible to grow evergreen broad-leaved trees over the cold winter. This offers the planting options to create green environment. Thus, it became worth investigating what kinds of evergreen broad-leaved plants could stand in Seoul during the winter. Ivy (Hedera helix) has been chosen in the current study which is a well-known native and ornamental plant in Europe. It grows in warm condition in general. The current study tracked $H$. helix which is evergreen cover plant over winter in order to evaluate the possibility for utilizing this species as a climber or cover-plant in Seoul. We found that H. helix can survive over the winter and can be utilized to create evergreen environment in Seoul. It also implies that similar kinds of plants could be tested assuming the environment of Seoul is becoming more suitable for the plants originated from the warmer sites. H. helix is an option for elaborating outdoor environments in the city that lacks of green color.
\end{abstract}

Keywords: Hedera helix, evergreen plant, global warming, city environment.

\section{RESUMO}

Sobrevivência da hera durante o inverno para paisagismo em Seul, Coréia, devido à mudança climática

Devido ao aquecimento global, em Seul na Coreia do Sul, é plausível plantar árvores de folhagem perenes no inverno frio, oferecendo opções para criar um ambiente verde. Assim, é válido investigar quais tipos de plantas de folhagem perene poderiam sobreviver em Seul durante o inverno. Neste estudo, escolheu-se a hera-inglesa (Hedera helix), planta nativa da Europa utilizada como ornamental. Ela cresce em condições de temperaturas moderadas. Neste trabalho, investigou-se H. helix, uma planta de cobertura perene ao longo do inverno, a fim de avaliar a possibilidade de utilizar esta espécie em Seul. Descobriu-se que H. helix pode sobreviver durante o inverno em Seul. Isso significa que ela pode ser utilizada para criar um ambiente perene em Seul. Isto também implica que similares tipos de plantas poderiam ser testados assumindo que o ambiente em Seul está se tornando mais adequado para as plantas originadas de lugares quentes. Isto nos proverá maiores opções para elaborar ambientes ao ar livre na cidade que não é tão arborizada.

Palavras-chave: Hedera helix, planta verde, aquecimento global, ambiente da cidade.

\section{INTRODUCTION}

It is difficult to grow evergreen broad-leaved trees except evergreen spindle (Euonymus spp.) in Seoul, Korea because temperature during winter is very cold. This limits the development of green landscape. However, growing of the evergreens may be possible in near future due to the drastically changing climates, so-called global warming which is now a worldwide phenomenon(temperature in Seoul in January changed from $-7.2^{\circ} \mathrm{C}$ in 2011 to $-2.8^{\circ} \mathrm{C}$ in 2012 and $-1.8^{\circ} \mathrm{C}$ in 2017 (http://sts.kma.go.kr) (HANSEN and HOUGHTON, 1998; HUGHES, 2000; ROOT et al., 2003). This means that the trees unhabituated from southern than Seoul could be planted in Seoul. Thus, it is worth investigating what kinds of evergreen broad-leaved trees could survive in Seoul during winter.

Among many kinds of evergreen ornamental plants, ivy (Hedera helix) has been chosen in the current study since it is a well-known ornamental plant of Europe (PAULSEN et al., 2010). This plant is native to Europe and the southwestern part of Asia and belongs to the Araliaceae family (HAUSEN and VIELUF, 1997). It is a perennial woody vine or climber, an herb, a woody subshrub, or rarely a tree which is variable in life form (GRIME et al., 1998; METCALFE, 2005). It grows well in warm condition in general as an indicator of warm conditions (ELLENBERG, 1998).

Net photosynthesis of $H$. helix declines with increasing degree of frost, but rises rapidly with increased warm

\footnotetext{
DOI: http://dx.doi.org/10.14295/oh.v24i4.1250

(1) Received in 02/07/2018 and accepted in 24/10/2018

(2) Jeju National University, Department of Plant Resources and Environment, Jeju, Korea.

(3) Phyto-Research Institute, Seoul, Korea;

(4) Sangmyung University, Department of Environmental Landscape Architecture, Seoul, Korea. *Corresponding author:1jh0830@smu.ac.kr

Licensed by CC BY 4.0
} 
temperature. Photosynthetic depression in frost-enduranceinduced leaves does not appear to be caused by feedback inhibition via assimilate accumulation (Bauer et al., 1996). However, it is known that weeks of mild frosts appear to limit the distribution of $H$. helix although tolerance of frosts may be induced (METCALFE, 2005).

The unproven fact is $H$. helix could survive in Seoul where severe winter comes every year kept it from being planted in Seoul. The objective of this study is to know if $H$. Helix could survive over winter. In the present investigation
Ivy was planted and evaluated in four different locations in Seoul.

\section{MATERIALS AND METHODS}

$H$. helix were planted in four locations in Seoul on February $\left(-1-13{ }^{\circ} \mathrm{C}\right.$, winter $)$ and June $\left(20-33{ }^{\circ} \mathrm{C}\right.$, summer $)$ in 2011 were evaluated and compared (http://www. weatheronline.co.uk). The description of four locations are in Table 1.

Table 1. Description of four different planting locations of Hedera helix in Seoul.

\begin{tabular}{|c|c|}
\hline Locations & Description of Planting site \\
\hline Chang-dong in Dobong-gu & Exposed to road-side \\
\hline Ssangmun-dong in Dobong-gu & Surrounded by buildings \\
\hline Gongneung-dong in Nowon-gu & Surrounded by trees \\
\hline Bangi-dong in Songpa-gu & Planted open space to have enough light \\
\hline
\end{tabular}

In order to determine the greenness of those species in winter, 20 replications of biomass, dry mass, and water contents of leaves were measured at summer and winter. Leaf areas were measured by the pixel numbers in the images using Adobe Photoshop software (ver. 7). Photosynthetic Photon Flux Density (PPFD) measured leaf color using LI-210R photometric sensor (LI-COR biosciences, Nebraska, United States) were separated into $\mathrm{L}$, a, and b (Hunter value). The amount of chlorophyll, which is related with photosynthesis, was expressed in Soil and Plant Analyzer Development (SPAD) value. Student's t-test was used for the comparison of the growth condition such as greenness of leaves of two seasons.

\section{RESULTS AND DISCUSSION}

In general, $H$. helix is planted close to the building so that it can climb on the wall. Due to this nature of such planting site, the light of each site cannot be the same. In this study, PPFD in full sun and planting site of each planted site varies ranging from 1,100 to 1,480 and from 64 to 130, respectively (Table 2 ).

Table 2. Relative Photosynthetic Photon Flux Density (PPFD) rate of shade to full sun under different planting locations of Hedera helix in Seoul.

\begin{tabular}{|c|c|c|c|}
\hline Locations & $\begin{array}{c}\text { PPFD in full sun } \\
\left(\mu \mathrm{mol} \cdot \mathrm{m}^{-1} \cdot \mathrm{sec}^{-1}\right)\end{array}$ & $\begin{array}{c}\text { PPFD in planting site } \\
\left(\mu \mathrm{mol} \cdot \mathrm{m}^{-1} \cdot \mathrm{sec}^{-1}\right)\end{array}$ & $\begin{array}{c}\text { Relative PPFD of planting } \\
\text { site to full sun }(\%)\end{array}$ \\
\hline Chang-dong in Dobong-gu & 1,100 & 64 & 5.82 \\
\hline Ssangmun-dong in Dobong-gu & 1,480 & 75 & 5.07 \\
\hline Gongneung-dong in Nowon-gu & 1,325 & 130 & 9.81 \\
\hline Bangi-dong in Songpa-gu & 1,270 & 89 & 7.01 \\
\hline
\end{tabular}

Consequently, the relative PPFD of plant site to full sun is from 5.07 to 9.81 . There are differences among those cites; however, the variation does not seem to be very high to prevent the growth conditions of plants at each site from cross-comparisons. Evaluations of the growth conditions of H. helix in four locations in Seoul on February and on June with naked-eyes showed that plant at each site had green leaves without damages over the winter, which is very promising result for introducing $H$. helix in Seoul (Figure 1). 


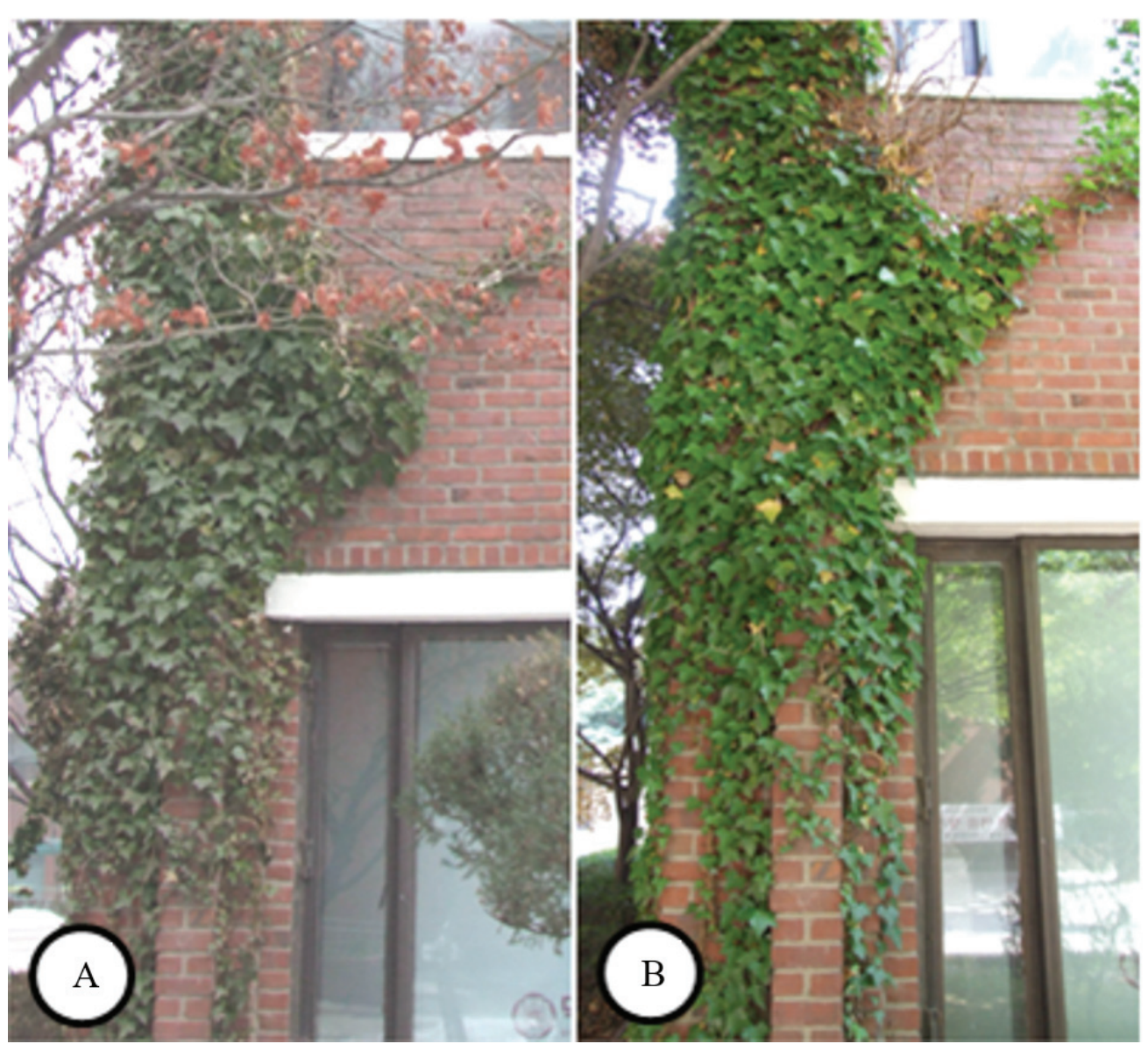

Figure 1. Leafy greening difference of Hedera helix during winter and post-winter season in Seoul. A: winter season, B: post-winter season.

Almost all locations had differences between winter and summer in SPAD, fresh weight, dry weight, water content, leaf area, and water content per leaf area (Table
3). Interestingly, the values of the traits collected in summer were lower in most cases and none of the characters showed higher values that were collected in winter.

Table 3. The comparison of growth in Hedera helix during winter and post-winter season in Seoul.

\begin{tabular}{|c|c|c|c|c|c|c|c|c|c|c|c|c|c|}
\hline \multirow[t]{2}{*}{ Locations } & \multirow[t]{2}{*}{$\square$} & \multicolumn{2}{|c|}{ SPAD $^{x}$ unit } & \multicolumn{2}{|c|}{$\begin{array}{l}\text { Fresh weight } \\
\qquad(\mathrm{g})\end{array}$} & \multicolumn{2}{|c|}{$\begin{array}{l}\text { Dry weight } \\
\text { (g) }\end{array}$} & \multicolumn{2}{|c|}{$\begin{array}{l}\text { Water content } \\
\qquad(\mathrm{g})\end{array}$} & \multicolumn{2}{|c|}{$\begin{array}{l}\text { Leaf area } \\
\left(\mathrm{cm}^{2}\right)\end{array}$} & \multicolumn{2}{|c|}{$\begin{array}{c}\text { Water content per } \\
\text { leaf area } \\
\left(\mathrm{mg} \mathrm{cm}^{-2}\right)\end{array}$} \\
\hline & & $02 / 06$ & $06 / 04$ & $02 / 06$ & $06 / 04$ & $02 / 06$ & $06 / 04$ & $02 / 06$ & $06 / 04$ & $02 / 06$ & $06 / 04$ & $02 / 06$ & $06 / 04$ \\
\hline \multirow{2}{*}{$\begin{array}{l}\text { Chang-dong in } \\
\text { Dobong-gu }\end{array}$} & Mean & 55.77 & $50.54^{* * *}$ & 0.92 & $0.49^{* * *}$ & 0.37 & $0.15^{* * *}$ & 0.56 & $0.36^{* *}$ & 49.56 & $35.10^{* * *}$ & \multirow{2}{*}{11.2} & \multirow{2}{*}{10.4} \\
\hline & SE & 1.33 & 2.25 & 0.07 & 0.04 & 0.03 & 0.02 & 0.05 & 0.03 & 2.08 & 3.16 & & \\
\hline \multirow{2}{*}{$\begin{array}{l}\text { Ssangmun-dong in } \\
\text { Dobong-gu }\end{array}$} & Mean & 43.09 & 44.82 & 1.09 & $0.90^{* * *}$ & 0.40 & $0.21^{* * *}$ & 0.71 & 0.68 & 62.00 & 58.50 & \multirow{2}{*}{11.5} & \multirow{2}{*}{11.6} \\
\hline & SE & 1.15 & 0.25 & 0.10 & 0.04 & 0.04 & 0.01 & 0.07 & 0.03 & 3.89 & 2.62 & & \\
\hline \multirow{2}{*}{$\begin{array}{l}\text { Gongneung-dong in } \\
\text { Nowon-gu }\end{array}$} & Mean & 49.12 & $29.03^{* * *}$ & 1.31 & $0.69^{* * *}$ & 0.50 & $0.19^{* * *}$ & 0.81 & $0.55^{* * *}$ & 62.25 & $41.78^{* * *}$ & \multirow{2}{*}{13.0} & \multirow{2}{*}{13.1} \\
\hline & SE & 1.51 & 1.01 & 0.04 & 0.06 & 0.03 & 0.02 & 0.02 & 0.05 & 2.20 & 3.03 & & \\
\hline \multirow{2}{*}{$\begin{array}{l}\text { Bangi-dong in } \\
\text { Songpa-gu }\end{array}$} & Mean & 52.95 & $48.32^{* * *}$ & 0.90 & $0.44^{* * *}$ & 0.38 & $0.13^{* * *}$ & 0.52 & $0.32^{* * *}$ & 52.78 & $28.78^{* * *}$ & \multirow{2}{*}{9.9} & \multirow{2}{*}{11.0} \\
\hline & SE & 2.33 & 1.12 & 0.04 & 0.02 & 0.03 & 0.07 & 0.02 & 0.01 & 2.10 & 1.12 & & \\
\hline
\end{tabular}

${ }^{\mathrm{x}}$ Soil and Plant Analyzer Development.

$*, * *, * * *$ Significant at $p<0.05, p<0.01, p<0.001$, respectively by ANOVA. 
The site where the leaves of $H$. helix were developed on the wall, it may be possible; that leaves of other trees growing in front of the building block the sun light to reach to the leaves of H. helix in summer, while there were no leaves to create shades in winter. However, all the data collected for SPAD, fresh weight, dry weight, water content, leaf area, and water content per leaf area indicated that H. helix in each location was healthy and even survived in winter. The hunter values (L, a, and b) can indirectly indicate the health of the leaves; the lower the value, the healthier the leaves
(Table 4). The $\mathrm{L}^{*}$ value of the leaves of $H$. helix in winter was lower than in summer for the two locations and higher in one location. The a* value in winter was higher in 3 locations. The $b$ value in winter was significantly lower in two locations. These results indicate that the growth conditions of $H$. helix in general, were better in summer. Nevertheless, the growth conditions of $H$. helix in each location in winter were still good enough to survive during winter. Bauer and Kofler (1987) reported the photosynthesis of H. helix recovered in 10 days after severely frosted.

Table 4. Hunter value changes of Hedera helix during winter and post-winter season in Seoul.

\begin{tabular}{|c|c|c|c|c|c|c|c|}
\hline \multirow{3}{*}{ Locations } & & \multicolumn{6}{|c|}{ Hunter value ${ }^{z}$} \\
\hline & & \multicolumn{2}{|c|}{$\mathrm{L}$} & \multicolumn{2}{|c|}{ a } & \multicolumn{2}{|c|}{$\mathrm{b}$} \\
\hline & & $02 / 06$ & $06 / 04$ & $02 / 06$ & $06 / 04$ & $02 / 06$ & $06 / 04$ \\
\hline \multirow{2}{*}{ Chang-dong in Dobong-gu } & Mean & 36.50 & $51.11^{* * y}$ & -11.80 & $-19.50^{* * *}$ & 32.40 & $42.60^{* * *}$ \\
\hline & SE & 1.19 & 4.22 & 0.71 & 0.48 & 1.12 & 0.95 \\
\hline \multirow{2}{*}{ Ssangmun-dong in Dobong-gu } & Mean & 39.90 & 38.90 & -14.50 & $-19.50^{* * *}$ & 34.44 & 36.30 \\
\hline & SE & 0.88 & 2.85 & 0.87 & 0.89 & 0.85 & 1.86 \\
\hline \multirow{2}{*}{ Gongneung-dong in Nowon-gu } & Mean & 37.22 & $47.90^{* *}$ & -14.33 & $-21.40^{* * *}$ & 32.10 & $43.70^{* * *}$ \\
\hline & SE & 2.93 & 2.66 & 0.50 & 1.30 & 1.82 & 1.20 \\
\hline \multirow{2}{*}{ Bangi-dong in Songpa-gu } & Mean & 41.00 & $33.50^{* *}$ & -12.50 & -11.40 & 32.90 & 30.70 \\
\hline & SE & 2.02 & 2.54 & 0.73 & 0.96 & 0.80 & 1.60 \\
\hline
\end{tabular}

$\mathrm{L}=0$ (black)-100(white), $\mathrm{a}=80$ (red)-80(green), $\mathrm{b}=80$ (yellow)-80(blue), measured at 3rd leaf from above.

$*, * *, * * *$ Significant at $p<0.05, p<0.01, p<0.001$, respectively by ANOVA.

Ivy is an indicator of fairly warm conditions an Atlantic element of the European flora sensu, having an essentially southern and western distribution: ivy is classified as European southern-temperate (ELLENBERG, 1988; PRESTON and HILL, 2007). Within the Scandinavian-Atlantic sub-element, the occurrence of ivy is limited by an isotherm of $-4{ }^{\circ} \mathrm{C}$ (HAFSTEN, 1956). Climate of Seoul is classified as Dwa (Cold and dry winter and hot summer) according to Köppen climate classification. However, those ivy plants survived in Seoul although the minimum temperature in winter of 20092010 in Seoul was $-9{ }^{\circ} \mathrm{C}$ (http://www.weatheronline.co.uk).

\section{CONCLUSIONS}

The results indicated that the growth conditions of $H$. helix are good enough to survive during winter in Seoul. It indicates that it can be utilized to create evergreen environment in Seoul implying that similar kinds of plants could be planted assuming the environment of Seoul becomes more suitable for the plants originated from the warmer places, providing us with more options for the city which lacks of green color.

\section{ACKNOWLEDGEMENTS}

This research was supported by a grant of the National Institute of horticultural and herbal science R\&D Project through the Rural Development Administration (RDA) (grant number: PJ011892022018).

\section{AUTHORS CONTRIBUTIONS}

Y.S.C. D0000-0003-3121-7600: data analysis and manuscript preparation. Y.N. (1)0000-0003-0827-7461: data collection, data analysis, and manuscript review. J.H.L. (D0000-0002-9737-2681: design of this experiment and manuscript review. Y.S.C. and Y.N. are equally contributed.

\section{REFERENCES}

BAUER, H.; KOFLER, R. Photosynthesis in frosthardened and frost-stressed leaves of Hedera helix L. Plant, Cell \& Environment, v.10, n.4, p.339-346, 1987. DOI: https://doi.org/10.1111/j.1365-3040.1987. tb01615.x

BAUER, H.; PAMER R.; PERATHONER, C.; LOIDOLT-NAGELE, M. Photosynthetic depression in leaves of frost-hardened ivy is not caused by feedback inhibition via assimilate accumulation. Journal of Plant Physiology, v.149, n.1-2, p.51-56, 1996. DOI: https://doi. org/10.1016/S0176-1617(96)80172-6 
ELLENBERG, H. Vegetation Ecology of Central Europe. 4th ed. Cambridge: Cambridge University Press. 1998. 756p.

FISCHER, A.; FELLER, R. Seasonal changes in the pattern of assimilatory enzymes and the proteolytic activities in leaves of juvenile ivy. Annals of Botany, v.74, n.4, p.389396, 1994. DOI: https://doi.org/10.1006/anbo.1994.1132

GRIME, J.P., HODGSON, J.G.; HUNT, R. Comparative plant ecology: a functional approach to common British species. London: Springer, 2014. 742p.

HAFSTEN, U. Pollen-analytic investigations on the late Quaternary development in the inner Oslofjord area. Universitetet i Bergen, Arbok. Naturvitenskapelig Rekke, 1956. 3-161p.

HASEN, J.E. Sir John Houghton: Global Warming: The Complete Briefing. Journal of Atmospheric Chemistry, v.30, p.409-412, 1998. DOI: https://doi. org/10.1023/A:1006043116343

HAUSEN, B.M.; VIELUF, I.K. AllergiepflanzenPflanzenallergene: Handbuch und Atlas der allergieinduzierenden Wild- und Kulturpflanzen. Kontaktallergene. Landsberg, Munchen: Ecomed Verlagsgesellschaft mbH, 1997. p.147-149.
HUGHES, L. Biological consequences of global warming: is the signal already apparent?. Trends in Ecology \& Evolution, v.15, n.2, p.56-61, 2000. DOI: https://doi. org/10.1016/S0169-5347(99)01764-4

METCALFE, D.J. Hedera helix L. Journal of Ecology, v.93, n.3, p.632-48, 2005. DOI: https://doi.org/10.1111/ j.1365-2745.2005.01021.x

PAULSEN, E.; CHRISTENSEN, L.P.; ANDERSEN, K.E. 2010. Dermatitis from common ivy (Hedera helix L. subsp. helix) in Europe: past, present, and future. Contact Dermatitis, v.62, n.4, p.201-209, 2010. DOI: https://doi. org/10.1111/j.1600-0536.2009.01677.x

PRESTON, C.D.; HILL, M.O. The geographical relationships of British and Irish vascular plants. Botanical Journal of the Linnean Society, v.124, n.1, p.1-120, 1997.

ROOT, T.L.; PRICE, J.T.; HALL, K.R.; SCHNEIDER, S.H. Fingerprints of global warming on wild animals and plants. Nature, v.421, n.6918, p.57, 2003. Doi: https://doi. org/10.1038/nature01333 